Originalveröffentlichung in: Alex de Voogt, Joachim Friedrich Quack (Hg.), The idea of writing.

Writing across borders, Leiden ; Boston 2012, S. 219-243

\title{
OLD WINE IN NEW WINESKINS? \\ HOW TO WRITE CLASSICAL EGYPTIAN RITUALS IN MORE MODERN WRITING SYSTEMS
}

\author{
Joachim Quack
}

\section{Ritual Texts and How to Write them in Demotic Egyptian}

In Ancient Egypt, ritual texts are an important part of the culture. They are among the earliest attested longer texts, and they continue to be used down to the first centuries $\mathrm{CE}$. In quite a few cases, we can even see how the very same compositions were used for almost three millennia-or at least approximately the same compositions since in practice, some divergences in wording are the rule rather than the exception. This entails, however, that the language used in the ritual formulae is very different from the language in actual use among the population - the effect is likely to have been similar to the use of Latin in church service during medieval and modern times.

Such a divergence has repercussions when it comes to the writing system used. There is no problem as long as you use traditional writing systems for rendering traditional formulae because the linguistic elements needed for classical Egyptian speech can easily be represented in hieroglyphic and hieratic writing. In actual realisation, hieratic ritual papyri even of the second century CE normally do not pose really serious obstacles to understanding them, even though the orthography of some selected few words might cause trouble.

The situation becomes considerably more difficult once you go beyond this restricted circle. There was a growing tendency to write such ritual texts, even if they were linguistically very much in a traditional register of classical Egyptian language, in the new medium of demotic script. Quite a few manuscripts of this type known by now, especially an ostracon (oHor 18) with a ritual for purification and protection of the king and the Apisbull from Memphis (Quack in press), the funerary papyrus Louvre E $345^{2}$ (Smith 1979), an ostracon from Thebes with a complex liturgical hymn (Smith 1977; Smith 1999), a stela from Akhmim with a solar hymn (Vleeming 1990; Vleeming 2004), a late Ptolemaic or early Roman wooden tablet with a hymn to the uraeus-deity (Widmer 2004), an ostracon with a hymn 
to the sistrum-play (Quack 2001), and a relatively substantial number of liturgical compositions on papyrus from Soknopaiou Nesos, mostly only available through preliminary reports (Hoffmann 2002; Hoffmann in press; Widmer 1998; Widmer 2005; Widmer 2007), plus some funerary compositions (Smith 2009a: 392; Smith 2009b; Smith 2010; Smith in press).

These texts have, on first look, one overarching similarity: they look strange and quite incomprehensible to somebody accustomed to demotic texts; and even if they were transcribed back into hieroglyphs, they would look equally strange to somebody accustomed to ritual texts in hieroglyphic and hieratic writing.

However, already now it should be stressed that while those are the compositions which abound in the orthographies I am studying here, now and again we can encounter them also in other, mainly literary, texts, ${ }^{1}$ be it as single archaic lexems in an otherwise "normal" demotic texts or as chunks of archaic language in a text which is inhomogeneous in its language, like the Ritual for Entering the Chamber of Darkness. ${ }^{2}$ There are even some plausible cases of "unetymological" writing making use of word-groups in administrative and documentary texts (Lippert \& Schentuleit 2010: $364-365$ ).

The orthography in question is normally called "unetymological" by modern scholars. Its basic point is that the demotic sign-combination for writing one word is used for the writing quite another, etymologically unconnected word. In order to illustrate the point, I would like to provide a number of actual cases:

The old noun $b w$ "place" is written as by "soul". ${ }^{3}$ The older negation $n n$ (no longer in use in contemporary texts) can be written as the group $n=n$ "for us" (besides another option of writing it with two one-consonantal signs for $n) 4^{4}$

The preposition of place, in older Egyptian $m$, but shifted in Demotic to $n$, can, besides a more normal orthography as $m$ or $n . m$ in these texts, also be rendered with the group for irm "together with" ${ }^{5}$ This sounds quite

Sometimes also in everyday compositions, if these, in giving a priestly title composed with the epithet of a god, have to come up with a way of writing it.

${ }^{2}$ For this composition, also known by the less appropriate name "Book of Thot", see the edition by Jasnow \& Zauzich (2005); and the study and translation in Quack (2007a; 2007 b).

3 E.g., pStrasbourg 3vs, $x+7,12.13 .14$; see for the writing J.F. Quack (2007a: 289) and Smith (2009a: 394 note 32 ).

4 See Smith (2005: 161 note c) with further references.

5 See Vleeming (2004: 628f. and $63^{2}$ note y); there are also cases of irm in the papyrus Insinger (coming from Akhmim as well as the stela in question) which I suspect to be writings of the preposition $n / m$, see Hoffmann \& Quack (2007: 363 note h). 
strange when considering only the historical transcription of the group, but in reality, the preposition "together with" had a contemporary pronunciation about like * $n m$, to judge form Coptic forms like $\overline{\mathrm{N}} \overline{\mathrm{M}}$.

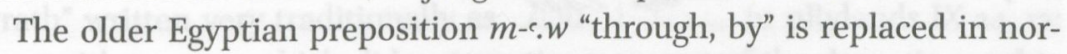
mal Late Egyptian and Demotic by the form $m$-ți. In ritual texts, when it is still used, it has an especially wide variety of possible writings. One possibility is to write it like $m$ - $w$ "in greatness", another like $m w$ "water" (Quack in press a), and finally, it can be written just with one-consonantal signs as $m w$ (Smith 2005: 144).

A group ${ }^{6}$ looking at first sight like $p_{3}$ wsç -tp "the one with the green head" is used several times for writing $p$ sw.t-tpi.t "first primeval time".?

The old expression ešs-hpr.w "of numerous shapes" is written with a group looking like ‘š "to call" followed by a sequence of one-consonantal signs giving $\underline{h} r b$ (Hoffmann 2001: 225).

We should, of course, be careful not to confuse genuine "unetymological" writing with cases of textual variants where in a ritual formula known elsewhere a genuine change in formulation has occurred. A case where this can become relevant has been discussed by Mark Smith (Smith in press). The original text runs as $r t k_{3}=k m-b_{3} h=k r t$ of your ka is in front of you, the foot of your ka is behind you." (Attested as such, e.g., in PT 18b (spell 25)). In a demotic papyrus in the Bodleian library transmitting a copy of this ritual formula, the noun $r t$ "foot", is written as if it were the verb $r w c ̧$ "flourish", giving the sentence a surface meaning "may your ka flourish before you, may your ka flourish behind you". Since both words are current in demotic, and furthermore even have significantly different pronunciations (Coptic form of $r t \underline{t}$ is PaT; Cop-

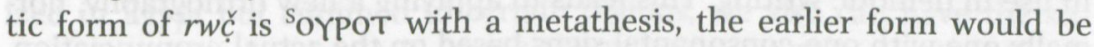
*PoYoT; other dialects have ${ }^{\text {BM }}$ epoYoT),${ }^{8}$ I fail to see why the one should be used as deliberate unetymological writing of the other. Rather this is a case of the classical phenomenon that Egyptian texts can have shifts in formulation which lead to the creation of a genuinely new sense (Pries 2011). The fact that in the case of this rather frequently attested text this would be the only manuscript to show such a deviation cannot

${ }^{6}$ By the term "group" I designate a demotic line-sequence which goes back to a combination of several signs (normally two- or three-consonantal signs with their phonetic complements) but which, on a synchronic perspective, cannot be meaningfully broken down into its original constituents.

7 Widmer (2004: 668 and 678 with note 47); Quack (2007a: 281 with note 71 ); for a similar hieroglyphic writing see Quack (2009d: 141).

${ }^{8}$ The letters S (for Saidic), B (for Bohairic) and M (for Middle Egyptian) indicate different Coptic dialects. 
count as a counter-argument since all experience with textual criticism shows that many variants are products of a single scribe and attested only once.

\section{Necessary Distinctions of Different Cases of Writing Words in Demotic Egyptian}

In order not to confuse the issue, it is necessary to draw some clear distinctions which have not always been respected in previous discussions. Firstly, there are words which do not have a well-documented earlier attestation or fixed orthography but only become normal in Demotic. Those have, of course, no established traditional orthography at all. The normal way is to write them simply with one-consonantal signs plus the appropriate determinative. In rare cases, a short demotic word-group with fixed vocalic value can be incorporated, as in sy-thy.t.t. "danger" where the first group is the one for sy "son". ${ }^{9}$ Since such words do not have any traditional "etymological" form of orthography, we can obviously not speak of an unetymological writing at all (contra Stadler 2006: 202 n. 4).

The second case are words which are attested in earlier Egyptian texts and also normal in demotic texts, but do not continue to use the same orthography. Those have not, up to now, been included in any discussion of "unetymological writing" in demotic, simply because demotists are too used to encounter them in their new orthography to feel in any way surprised by their outward form. The most frequent reason for coming up with a new orthography is that the traditional word-sign is no longer in use in demotic writing. This leads to applying a new orthography, normally one with one-consonantal signs based on the actual pronunciation. A god case is the word for "fight". In older Egyptian it occurs as ch $z$ with the word-sign 1.7 . This sign does not exist in demotic. Due to regular phonetic developments, the contemporary pronunciation was $3 h$ and this is how the word gets written in demotic orthography.

In some cases, we can observe that the switch from a traditional to a modern writing is not coterminous with the rise of demotic writing as such, but only occurs in later stages. Especially early demotic writing,

9 The word has no certain pre-demotic attestation; it might be recognized in the groupwriting 它। 04 म 
which is comparatively close to traditional hieratic forms, still makes use of some groups abandoned later. Thus, we still find the word bs.w "divine wrath" written very traditionally as 25,5 with a group which did not continue as part of the demotic graphic inventory, while later texts at least from the Ptolemaic period onwards write the word with one-consonantal signs as $b w(3) .^{10}$

A subtype of this case are words where phonetic shifts of individual words have made it impractical to further use their traditional orthography even if that still exists for other derivations of the same root. A good example is the word hpr.w "shapes, forms". Originally, it is derived as a noun formation from the verb hpr "to exist, to take shape". Both the verb and the noun are still used in demotic (and Coptic) language, and there is a specific demotic group for the verb consistently used. However, for the noun a sound shift plus later a metathesis have occurred, leading to a writing with one-consonantal signs as $\underline{h} b r$ or later $\underline{h} r b$, Coptic $2 \overline{\mathrm{P}} \mathrm{B}$. The group for the verb is no longer used in the noun.

We can also adduce the case of the word hry "what is down". This is clearly a derivation of the preposition $\underline{h} r$ "under". But while older Egyptian writings consistently show the connection by using the same core part of the writing, in demotic the word "what is down" is always written with one-consonantal signs, not with the historical group used in the preposition. The reason is probably that the preposition $\underline{h} r$, dropping the final $r$ in pronunciation, became 2a in Coptic, while the adverb, pronounced 2Pd, sounded quite different.

In rare cases, especially when a phonetic development is not generalized in Egypt but confined to certain regions, we also can have the situation that the historical form (with a fixed group) is normal while an unetymological form corresponding to the sound-shift is very rare. We can produce the example of $n b$ "lord" where the group is normal, while we rarely have a form $n p$ written with one-consonantal signs and corresponding to a shift to Naח attested in some Coptic upper Egyptian dialects." Perhaps the choice of the writing has also to do with the different treatment of the word according to whether it is used in the status absolutus or the status constructus.

\footnotetext{
${ }^{10}$ For the correct etymological connection of the often misunderstood word, see Smith (1987: 119).

"Attested pRhind I 5d6, see Quack (1991: 97, n. 30). The phonetic reason for this writing still goes unrecognized in Smith (2009a: 643 n. 98).
} 
This leaves only the third type as really relevant, namely words no longer a normal part of active language during the Late, especially GraecoRoman period. Even with them, we have to be careful what is still used and what not, since that can involve quite similar-seeming words.

A good case in point are nominal derivations of the ancient root $w \check{c}$ " to order, to decree". While a masculine word $w t$ "order" (ancient $w \breve{c})$ is still functional in Demotic, its feminine counterpart (ancient wç.t. "decree") had died out. When the feminine word occurred in some religious compositions, the only option for writing it actually attested is using the word $w t . t / w t y . t$ "calamity" (ancient wt.t..$^{12}$

\section{Methodological Considerations}

After having singled out what is relevant and what not, we can now focus on the actual phenomenon that writings usual for one word, normally a common demotic one, are used for a quite different, uncommon one.

Detecting all relevant cases can be hampered by a methodological problem. In some cases, the new orthography does not produce any acceptable overall sense in the text, so that it is relatively easy to arrive at the conclusion that it must stand in an unetymological way for something quite different. The only real problem is to find a good solution for what is actually meant.

It can be much more difficult if the new writing does not, in itself, produce nonsense but might be considered as a semantically viable formulation. If no hieroglyphic or hieratic parallel with a clear orthography is at hand, the decision can become difficult. In such cases, the different temper of individual scholars can lead them to varying approaches. Normally, they argue that the writing should be taken at face value "as it stands" (Smith 2009a: 278 n. 43). This sounds at first like a solid way of handling a text. On closer inspection, however, it can turn out to be more problematic than it seems.

If we say, in deciding how to semantically decode a specific writing, that we take a certain writing "as it stands", this implies that the ancient writer has fixed a default value for a certain word, namely a "normal"

\footnotetext{
${ }^{12}$ See Smith (1987: 117). Erroneously Stadler (2006: 202) who has not distinguished the masculine and feminine form. His rejection of the understanding of wty.t as "decree" in pVienna 12006 is ill-founded, as the "decree of Re" mentioned in that text is a composition attested also in hieroglyphic texts, see Quack (2008: 367 n. 221).
} 
orthography, and would only in exceptional cases resort to another, "unetymological" writing for it. This is, of course, not how things really stand. In all cases I have presented here for uncommon words being written by the use of groups for quite different words, there is no demotic attestation at all for the use of the historical writing of the uncommon word. Thus, the scribe had no other choice for the uncommon word but to write it with the signs in use for the common one. This means that, if we have a text known to draw on uncommon vocabulary, in principle the one orthography can stand equally well for both words, and only considerations of context can provide arguments for a decision.

\section{Possible Explanations of the Writing}

An important question is of course why such a way of writing came into being. We can probably exclude the hypothesis that it was just an intellectual exercise where one priest tried to impress on another with his cleverness. Certainly the reading culture of these manuscripts would not be apt to such an attitude; after all, they were intended to be used in rituals with a clear goal for the community, not read for the fun of a specific individual.

We can be a bit less certain that it was not, in a more serious variant of this, a trial item for checking the competence of priests. There is one piece of positive evidence that reading competence could be tested by the administration. In a Greek-language papyrus from Tebtunis (pTebtunis 291; Grenfell, Hunt \& Goodspeed 1907: 54-58), we have a document concerning some adolescent candidates for priesthood. In most cases, the descent from a priestly family by the side of the father and the mother is the sufficient basis for allowing them to be circumcised, an operation at that time officially forbidden and only allowed on application for Egyptian priests (for whom it was a necessary prerequisite for temple service). In one of the cases, however, the candidate does not prove his priestly descent but shows his competence by being able to read the hieratic and the Egyptian script from a hieratic book fetched from the temple. ${ }^{13}$ I suppose that the terminology means Hieratic and Demotic writing. This proof by competence is explicitly justified by reference to a recent imperial memorandum allowing this procedure alternatively to the proof by

\footnotetext{
${ }^{13}$ For the interpretation of this passage, see Quack (2005: 101).
} 
descent. Thus, reading competence in rituals was of importance when it came to the question of being allowed to priesthood, and being a priest meant material benefits. So there is some element of social competition for good jobs tied up with competence in reading ritual texts, and making the job more difficult would in effect mean to diminish the field of potentially successful candidates. Still, the context of the manuscripts in question is not really in favour of such a setting.

One line of thought applied to these orthographies was that they would act as a sort of internal commentary where writing was in itself giving an additional layer of meaning to the basic text (Smith 2oogb: 357). To cite one proponent of such an approach: "Unetymological writings are capable of endowing a text with multiple levels of meaning. Moreover, they can refer to beliefs and concepts recorded in other texts and allow these to be brought into relation with it. I suggest that their particular contribution to ritual texts where the aim is to actualise both what is said and written, is to enhance their reifying power and extend the range of what they can actualise by bringing these other things into play. If Bodleian MS. Egypt. a. $3(\mathrm{P})$ is to be assigned to this category of texts where the manner in which a word is written is just as important as the manner in which it is pronounced, then it is not difficult to see why unetymological writings appear with such profusion in it." (Smith in press).

I am not quite convinced that this line of reasoning is entirely correct, or at least it does not seem to hit the mark for the primary relevance, and some other scholars share my doubts (Hoffmann in press). If unetymological writing was primarily a means of laying a commentary on the text itself and expanding its semantic relevance, we would expect it to occur in relatively equal measure all over the text, for all sorts of the vocabulary regardless of being archaic or still in common use, and especially for the semantically most loaded verbs and substantives. The real distribution is quite different. The new and surprising orthographies are largely limited to those words for which there is no established demotic Egyptian written form, and this often goes concomitant with the fact that these words have died out in contemporary speech, or at least the specific forms of the words are no longer in use. But within this field, unetymological writings are by no means concentrated on words with highly loaded semantic content which would be in the centre of interpretation. They can also occur with prepositions or the negation or formative grammatical elements.

Furthermore, there are too many orthographies which do not really give a satisfactory new level of meaning to the text. If, for example, the preposition "by" is written as "water" or "in greatness", this hardly ever provides 
any acceptable new possibility of interpretation. Furthermore, while the cases where words with quite different meaning are used have been more in the focus of the discussion, we should not overlook the fact that in most cases, the new writings are just plain sequences of one-consonantal signs without any deeper meaning at all.

Another important aspect is that in the great majority of cases, we have only one or at most two different "new" orthographies for the words in question, ${ }^{14}$ and those are used consistently, without consideration of the specific context. Obviously, such an application makes it relatively difficult to consider them as a commentary, as the essence of a commentary is to adapt to the specific context it is commenting.

Actually, there is a remarkable stability over time and regions attested for many cases in question. We have, e.g., the ancient word çcw "evil, bad". In Demotic, this is written with the group for $t$ s "land", optionally with the added determinative of the dying man. We have this writing in the following texts: ${ }^{15}$

\section{- pBM 10507, late Ptolemaic or Early Roman, from Akhmim. ${ }^{16}$}

- Tablet Louvre E 10382 , early Roman period, perhaps from Dendara. ${ }^{17}$

${ }^{14}$ A rare case of two different writing possibilities is the word gmhsw for a sacred falcon which can be written as $g m-h s$ "finding praise" in the book of Thot and as $g m-h s$ "finding excrements" in pVienna D $695^{1}$ (different determinatives used for the second part), see Hoffmann in press. The reason for the divergence is perhaps that $h s$ "praise" gradually fell out of normal use (it is hardly attested in Coptic). In the case of the four different writings for the preposition $m-\varepsilon, w$, local dialect differences are relevant, including the question which dialect had already lost the specific sound c.

${ }^{15}$ In principle to be added to the documentation is an unpublished hieratic manuscript of the Book of the Temple (from Soknopaiou Nesos in the Fayum) where reversely ç̌w is written in an expression which etymologically clearly contains $t 3$ "land". Also, a difficult hieratic text shows a variation between $t_{3}$ and $c ̧ w$ in different manuscripts, see Goyon (1999: 91 n. $5^{2}$ and pl. XXXIX [51, 7]); with the latter probably being the better reading.

${ }_{16}$ Quack (1999a: 41). I would insist on this interpretation against the opinion of Smith (2009a: 262) who thinks that the text makes good sense "as it stands". Firstly, while formulations like "you will be save from all evil things" are very frequent in Egyptian texts, an expression "spirits of the earth" is otherwise completely unattested (and "spirits on earth", as he tries to translate now in Smith (2009a: 262), would be ihy hr p $t_{3}$ ), and secondly, the orthography as $t 3$ is the only attested writing of ç ${ }_{c} w$ "evil" in demotic texts. For writings of ihy "thing" as if it were ihy "spirit", see, e.g., the expression swh- ihy heading the indications for the manual practice and the objects used in pMag. LL which are obviously to be understood as "collection of things" but are normally written as if they meant "collection of spirits"; for the translation see Quack (2008: 334 with note 17).

${ }_{17}$ Widmer (2004: 664). The actual place of origin is unknown but the best parallels for the text are hieroglyphic inscriptions from Dendara. In any case, the writing seems upper Egyptian, not Fayumic. 
- pCarlsberg 182, second century CE, from Tebtynis in the Fayum (Osing 1998: 211 and 212 note e).

- pVienna D 6527, second century CE, from Soknopaiou Nesos in the Fayum (Quack 1999b: 461).

- pMag. LL, third century CE, from Thebes (Griffith \& Thompson 19041909, volume III, p. 92).

\section{Tests of Frequency}

In order to put the writings into a correct perspective, some statistics about their relative frequency are needed. I have chosen to limit my sample to two single texts, namely the writing tablet Louvre E 10382 and the ostracon BM 50601, and that for several reasons. Firstly, the limited amount of data contained in them makes it faster to process them and to formulate preliminary hypotheses which can then be checked against the bulk of the documentation (which would be very difficult to analyze without any guiding premise). Furthermore, both have been treated in full in good recent publications, and most especially, the text contained in them is known from hieroglyphic parallels, thus there is rarely any doubt about the semantic interpretation of the actual writing. ${ }^{18}$

The writing tablet contains about 63 different words (some occurring several times). Of these, about 32 (including personal suffixes) are words at home in demotic and written in a completely normal way; either with historical groups or as sequences of one-consonantal signs which are the accepted way of writing these words also in non-religious texts. 28 are written with one-consonantal signs, ${ }^{19}$ either totally or for a relevant part of them,$^{20}$ and not part of the normal demotic vocabulary. ${ }^{21}$ For none of those words, there would have been an obvious historic demotic group at hand to write them.

${ }^{18}$ These criteria would also apply, in theory, to the ostracon Corteggiani 1 and the stela from Akhmim, but those texts do not contain enough relevant orthographies to make them meaningful items for statistical analysis.

19 The use of $m$ for the preposition has been included here, as the normal demotic orthography for this preposition would be $n$. The presuffixal form im $f$ has been counted separately.

${ }_{20}$ I have counted the instances of $h_{3}$ and $m-h_{3}$ as phonetic alphabetical writing, not as unetymological writing proper, contrary to Widmer (2004: 677), since $h_{3}$ with the determinative of the man with the hand to the mouth does not correspond to any normal writing for hy "to be elevated, high".

${ }_{21}^{21}$ The demarcation between words forming part or not part of demotic vocabulary can be in doubt for some of them, but this is unlikely to substantially change the picture. 
Only three cases present words written, either as complete phonetic part or significant part of it, with a group otherwise serving to write a clearly unrelated demotic word, namely the following: the word "evil, bad" (ancient $\stackrel{c}{c} w$ ) is written with the group for $t 3$ "earth", but followed by its appropriate determinative of the dying man. The word "plebs" (ancient rhy.t) is written as 3 (-he.t, making use of the group for he.t "body" for the final part of the word. The word psw.t tpi.t "first primordial time" is written as $\langle p 3\rangle$-wt-tp "the one with the green head" (or, perhaps even more probably, "the first papyrus plant"). All three writings are not specific to this single text but well attested in other manuscripts as the general and typical writing of the word in question whenever they occur in demotic. In the first one, the use of the specific determinative distanced it so much from the word "earth" that clearly there was no intention to create an ambiguity or deeper meaning. The second one obviously does not have any really "deeper meaning" since the first part $3 l$, written alphabetically and without determinative, does not mean anything at all. In the third one, a connection with Osiris as the "green-headed" god, ${ }^{22}$ proposed for other attestations of the expression (Smith 2005: 210), does not seem particularly relevant for the hymn in question where Osiris does not play any role.

Thus, in this case, the image is crystal-clear: There is no predilection at all to use "meaningful" writings with word groups to create an additional layer of associations or commentary. Rather, you would simply use oneconsonantal signs to spell out the word in question (of course according to current pronunciation, not to the historical old form). If available, word-groups of fixed vocalic value would be used in order also to indicate the vowels for the recitation, but those were few and far between them, and since all were the only actually attested demotic orthographies of the words in question, the use of this writing would not have evoked some esoteric deeper hints to a reader accustomed to this sort of texts (as most of their users would certainly have been).

The ostracon presents a somewhat longer text. There are about 115 different words in it. Of those, about 65 (including personal suffixes) are written in a completely normal way. About 30 are somewhat alphabetically

${ }_{22}$ As a matter of fact, although Osiris is iconographical depicted with a green head (for reasons discussed by Banaschak \& Grothoff 2000), actual attestations of an epithet $w z c ̧-t p$ are not only enormously rare but even never refer to Osiris at all, see Leitz et alii (2002: 262). 
written, although sometimes only for parts of the words. ${ }^{23}$ The number of writings which might be called "unetymological" comes at about $20^{24}$ On first sight, this looks like a significantly larger number than in the writing tablet. However, several points have to be kept in mind. Firstly, some writings are bordering on cases which can hardly be called "unetymological" since, while at variance with traditional hieroglyphic spelling, they are much at home in demotic texts outside the religious sphere, e.g., $i w$ (written like "income") for $i s w$ "praise". ${ }^{25}$ Furthermore, this spelling with complete words is by far the most frequent with words like particles and grammatical elements which should be semantically the least loaded. Thus, we have $t w s t$ (like the proclitic pronoun of the $2 \mathrm{sg}$. fem.)

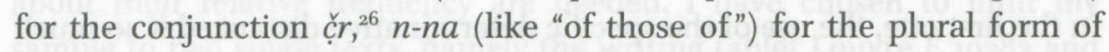
the genitive $n . w,=n$ like the suffix "we" for the formative element of the sçrm.n-f-tense, $n t i$ (like the relative converter) for the feminine form of the genitive n.t, w-wnw.t (like the word "hour" with an additional alphabetic $w$ in front of it) for the auxiliary verb wnn "to exist" in a certain tense, ip (like the verb "to count") for the copula of the nominal phrase, ${ }^{27} t w=t-s . t$ (like "you gave a place") for the formation ti-si "while she is", $m h$ (like he verb "to fill") for the compound preposition $m$-ḩ.t "before", $n-n=n$ (like "for us") for the negation, and $t w-n=i$ (like "gave me") for the conjunction $t n w$ "every time when". Firstly, this leaves very few items where it could be even seriously discussed if the new writing gave an intentional layer of meaning. Secondly, the very fact that more than half of the cases where complete demotic words are used for unetymological writing come from this semantically rather "empty" category of words demonstrates clearly that considerations quite different from an intention for "commentary" or "deeper meaning" were the driving factor.

The following are the actual cases with nouns and full verbs: The participle of the verb $n b i$ "to fashion" is written with the group for $n b$ "lord" (1. 4); the verb in question is not otherwise used in demotic. Here, an "added meaning" would in principle make sense as a creator-god could justly be called "lord".

\footnotetext{
${ }_{33}$ This concerns sequences like $s$-šsp-p for sšp "light" and sh-hpr for shpr "produce".

${ }^{24}$ Assuming that the $t w=n-n=f$ for $n c ̧ . . n=f$ is more likely to be a real variant than an unetymological writing.

${ }^{25}$ For demotic attestations of this word, see Ryholt (1999: 39).

${ }^{26}$ Hardly a very bold writing, since $m$-tw or even $t w$ are attested demotic writings for old $m$-črr.

${ }^{27}$ For other cases of this orthography, see Hoffmann (2001: 226).
} 
The word wy "limbs" is used for c.wi "the two arms" (1. 4); the dual is no longer existent in demotic and could not have been expressed correctly by any writing of the word really meant. The semantic area of the word actually used for the writing is so close to the original one as to leave little leeway for an added meaning.

The expression ksy.t kzi.t "high hill" is written as gy $n k 3$ "form of a bull" (l. 6). For the first word of this expression, a writing as $g y$ "form" is also attested in Mythus Leiden 10, 13. The second is otherwise unattested as adjective. The new writing, taken at face value, would have produced an acceptable sense in the context, and, were it not the known hieroglyphic parallels, might even have been accepted as what the text was intended to mean.

The word hnm "well" has been written at the end of 1.6 and afterwards been erased. It does not correspond to anything in the attested hieroglyphic parallels but could reasonably stand for the verb hnm "to unite". This verb is not part of the normal demotic vocabulary and all attestations of it are showing metathesis and sound-changes. Thus, there would have been no other orthography available. A literal translation as "the well of the ennead is in adoration for him" does not really make sense.

šy.t=f "his nose" is used for šw.tilef "his feathers" (1. 9). Here also, the word is not used in normal demotic. In the context, where the illumination of the sky is treated, the writing would hardly give an appropriate additional layer of meaning.

The expression $m t w r$ ' "word of the mouth" is used for the verb "to be successful" of which the most ancient form seems to be $m^{\text {' }} r$ but which in later periods was usually written as if it sounded like $m^{\prime} r t$ (l. 10). This verb is otherwise unattested in demotic or Coptic. A "literal" reading as "great is the speech of the mouth" would be possible in the context.

The city-name $n w . t$ "Thebes" is used for the sky-goddess $n w . t$ but with added determinatives of the sun-disk and the divine (1. 22). In this case, normal writings would have been at hand and the reason for the graphic choice is not quite obvious (it might have been the intention to indicate a different pronunciation but we have no clear evidence for that). In any case, the determinatives added preclude any effort at just taking the writing to actually mean "Thebes" although in a hymn to Amun, the main god of Thebes, the writing can be considered appropriate.

Thus, while some of the actually attested unetymological writings could be analyzed to give an additional layer of meaning, such an approach cannot convincingly be upheld for all of them. 


\section{Preliminary Conclusions}

We can now resume the results from these two texts into some preliminary hypotheses and the consequences for interpretation they entail. Firstly, even in most of the liturgical texts in classical Egyptian, if demotic writing is employed, more than half of the words still appear in the regular demotic orthographies for those very words. ${ }^{28}$ In itself, that proves nothing more than the principal continuity of Egyptian lexems through times. The fact becomes more meaningful, however, if we turn it the other way round: if a normal demotic writing for the word was available, normally no demotic scribe bothered to make up any unetymological writing for it. ${ }^{29}$ This, in itself, is a serious indication that there was no dominating drive for achieving an additional layer of meaning in those cases where "unetymological" writings where employed, because if that had been the case, why would the scribes hardly ever have worked it on words for which a traditional orthography was available for them? The fact that sometimes similar writings were employed even in administrative and documentary texts where clarity would be the intention, not the creation of ambiguity and second meanings, also militates against the "commentary"hypothesis.

Secondly, for words which did not have any traditional orthography in Demotic (and did not actually exist any longer in ordinary speech), the far more common solution was to employ purely alphabetical writings which did not allude to anything else at all. There was no urge felt by the scribes to look for writing solutions which could give additional layers of meaning.

Thirdly, writings employing groups for completely unrelated other words were most frequent with semantically rather "empty" prepositions and grammatical elements. Fourthly, when they were used for nouns or verbs, in most cases there was no really convincing additional meaning

${ }^{28}$ The only likely exceptions are texts containing mainly recondite divine and geographic names and epithets.

${ }_{29}$ A rare exception is the divine name $H w . t-H r$ "Hathor" which occurs once with the first element written as hç "silver" in Mythus Leiden 22, 24 and 25, as noted by Widmer (2004: 681). The writing provides a perfect indication of the phonetics if we suppose a state of the vowels as in the Saidic or Bohairic dialect where the word is pronounced 2aT (it would not function in Fayumic or Akhmimic where the form is $26 \mathrm{~T}$ ), but semantically, it seems rather weak, since Hathor is the "golden", not the "silver" goddess in Egyptian imagery. This writing is used only for Hathor linked geographically to Thebes and Dendara, and it might be a conscious effort of the scribe to indicate a particular pronunciation at home in that area. 
which could be produced by the process. Finally, the only really constant factor of "unetymological" writings using complete demotic word-groups is phonetics. Wherever we have sufficient external evidence for the pronunciation of the words in question, we can conclude that the word used in writing really had the very same sound-sequence or a close approximation of it. ${ }^{30}$

We should also note one additional point: Classical-Egyptian language ritual texts in demotic script do have "unetymological" writing on a regular basis. But contemporary classical-Egyptian ritual manuscripts in hieratic script, sometimes even of the very same compositions, do not normally have them. It would be quite surprising if the urge to lay an additional meta-layer on a text were so much greater with demotic than with hieratic scribes. This is most evident in the case of papyrus Bodleian MS. Egypt. a. $3(\mathrm{P})$ which has some hieratic and some demotic ritual texts. Only the demotic ones are characterised by "unetymological" writing. Why would the scribe have refrained from using it for the hieratic parts of the manuscript if he had really a substantial interest in providing such an additional layer of meaning?

However, the fact of the choice between hieratic and demotic writing to use for the ritual manuscripts is meaningful in itself. If some scribes preferred demotic script for ritual texts even though it forced them to use complicated non-etymological writings, there must have been other advantages to be gained (Hoffman in press). One point is perhaps the better legibility of demotic script. This might seem surprising to us, since modern Egyptologists normally deem demotic to be far more difficult. But the ancient training seems to have been different, with demotic as the normal writing system taught during the Late Period. Even more important is probably another point. The crucial part of a ritual is to recite it with correct pronunciation. Understanding the semantics of the spells by the recitator was much less an issue. This means that demotic script, by the very fact of being unetymological, was helpful for the performer. Instead of having to memorise lots of words not part of his active language, he could just use a manuscript with relatively clear indications for correct pronunciation.

30 Due to constraints of space as well as the highly special discussion needed for it, I refrain from demonstrating this in more detail; already Hoffmann (2001) has provided several good examples. 
The question of competence in a somewhat dead earlier phase of Egyptian language cries for introducing another piece of evidence up to now not much drawn into the debate about the sense of demotic "unetymological" writing. This is an onomasticon from the second century CE which lists of words arranged according to semantic groups (Osing 1998). The basic part of the text is written in hieratic, with a relatively classical orthography. But above many of the words, there is a supralinear gloss, often in demotic, and sometimes also in Greek letters with some additional demotic oneconsonantal signs for sounds not present in Greek (Osing 1998: 40-50). In most cases the glossing is concerned with questions of pronunciation of the whole word or parts of it (especially the stressed syllable which would be the only one to contain a full, unreduced vowel). In other cases, there can be also an indication of meaning, realised by the label "sort of...".

The demotic forms for the pronunciation are obviously to be seen on a level similar to the writings in the ritual texts we have discussed so far. Some examples should show this:

For the verb hri "to prepare" we have as a gloss the divine name of Horus, Egyptian $H r$. The word chry.t "noon time" is glossed by ih.t "cow". For mțw "staff", we have the sign for the number $10(m t+w)$. A verb prs of uncertain meaning is glossed by $p_{3}$ rsi "the south". hmy "enemies" is glossed as šmw "parents in law".

The obvious reason for these glosses is the training of ritual specialists. With its collection of words, many of them no longer in current use, and their classification according to semantic categories, this is a classical case of a reference tool. Even more, the second half of the papyrus collects specifically fundamental religious knowledge. This clearly shows how it was a manual for the specialist and helps further to situate the glossing. The knowledge of meaning and pronunciation of classical Egyptian was a precarious thing and in need not only of training as such, but even of written fixation.

One point is now of crucial importance: in this text we have a collection normally of individual words or at most very short statements. Thus, the idea proposed for the ritual manuscripts, that the "unetymological" writing should give an additional layer of meaning to the text, is hardly pertinent. After all, here we have single words which could be used in quite different contexts, and they do not form a coherent text. How could a single "unetymological" writing for any one of them effectively produce 
a context-sensitive commentary or additional meaning? Thus, only the advantage of indicating the correct sound more clearly comes out as overarching reason for choosing the demotic writing for rituals in classical Egyptian script, including either purely one-consonantal indications of the actual pronunciation, or groups for quite different words of identical or closely similar sound.

\section{Theoretical Questions}

Thus, we can certainly arrive at the conclusion that oral performance played an important part in choosing this notation. However, if we regard the situation from a theoretical point of view, we could say more about what happens here. The point is that we have become accustomed to regard certain Egyptian orthographies as "regular" because they got relatively fixed during the formative early periods of Egyptian writing. If we look at it from the synchronic point of view of the early Egyptians, for most words, in the beginning, writing was in some way "unetymological" because the basic signs used were gained by abstracting sounds and sound-sequences from the concrete objects depicted and applying them to these sound-sequences in general, independently of etymological connection. Establishing any sort of orthography meant creating writings which could become future norms but were not, at the time of their first establishment, already canonical-they only became the norm because time proved their practical usability.

What we have now with the writing system used for classical Egyptian texts in a more modern writing system is, I think, not fundamentally different from what went on during the formative phase of Egyptian hieroglyphic writing. Where applicable, signs with the value of several sounds were used; else recurrence to simple one-consonantal signs was the option. The only serious difference is about the basic material to be used. In the phonetic part of hieroglyphic writing, signs with the values of one, two or three consonants or whole words were available. By contrast, in demotic, for the signs with phonetic value, it only makes sense to differentiate between one-consonantal signs and groups (Quack 2009a; Quack in press b). Groups, however, practically always represent a writing of a complete word. Thus any writing of a demotic word which is not confined to oneconsonantal signs cannot avoid creating associations with a word. If the word is etymologically closely related, we would normally consider this as an etymological writing and not pay more attention to it. If, however, the 
word seems substantially different in meaning or etymology, we speak of unetymological writing and try to come up with explanations for it.

Perhaps this is not the best possible approach. Shouldn't we rather loosen our fixation on the seemingly word-fixed value of the demotic groups and go a step towards recognising them as signs for a sequence of several sounds, partially with fixed vocalic value? After all, in those cases which happen too regularly to be explicitly noted and commented, we actually do practice such an approach. For example, the complete group for the word $m n$ "to remain", including the determinative, is often used in Roman period manuscripts as part of the writing of the word mmy "daily". The groups for the verbs ini "to fetch" and iri "to do" are used freely for indication the sounds of $n$ and $r$ in specific phonetic situations (Zauzich 1998: $748 f$.). Nobody has up to now considered such writings under the same angle as that of the "unetymological" writings, perhaps because they seemed so normal. But frequency of attestation and theoretical classification are obviously different questions.

Thus, the phenomenon of writing in demotic ritual texts looses much of its seemingly specific nature. It is bound up with a general restructuring of the writing system occurring with the onset of Demotic in which, once again, clocks were set back to zero, and for establishing orthography you would start with what signs for single consonants or sequences of sound you had, basing yourself on the actual pronunciation. The only serious difference to the first formative period of Egyptian writing during the protoand early-dynastic period is that this time, vocalic value at least of some groups seems to have been fixed while the early development was characterised by the enormous abstraction achievement of disregarding vowels. ${ }^{31}$

This might bring up another point which I have withheld up to now. I have only spoken of rendering Egyptian-language ritual texts in demotic writing. But there are also cases where demotic writing is used for Semitic ritual texts, most especially the famous papyrus Amherst 63 (Quack 2oogb). If we look closely, on a structural basis things are not so different, with the only exception that here of course there is no traditional Demotic writing using word-groups possible for the Semitic words at all. But also here we have the situation that most words are written simply with

${ }^{31}$ As I have noted in Quack (2006), contrary to many theories of Graecocentric scholars, disregarding the vowels in writing was not simply a shortcoming but had real advantages, and besides it was an abstraction only possible if you clearly understood the difference between consonants and vowels. 
one-consonantal signs while in statistically much rarer cases, complete Egyptian groups were used, and perhaps also there with a fixed vocalic value. But the content as well as the language of the basic text obviously excludes that those Egyptian words were chosen to give an added layer of meaning.

Coming to a conclusion about the whole question of supposedly "unetymological" writing, it seems that it was tackled the wrong way in scholarly discussion, as far as theoretical implications go. It is no more than the logical result of the structure of the demotic writing system which gave you only one-consonantal signs and complete groups. If you had to write a word without established orthography, you could either simply take one-consonantal signs or, if it fitted in, a group. Using a group was much less frequent for the simple reason that it happened only infrequently that an etymologically completely unrelated word would provide a phonetically good fit for the word, or part of it, you wanted to write. It would be advisable to drop the term of "unetymological" writing altogether and label these writings just as "phonological". The theoretical background to the orthography was identical in all sorts of texts. The only reason why "unetymological" writing was so much more frequent in ritual texts than in other genres is that the traditional ritual texts contain many more words having died out in contemporary speech and being in need of creating an orthography for them. This means that there is no mysterious deeper meaning to the orthography of these ritual manuscripts. The only thing which remains is our technical difficulty to decode them, which is due to the fact that we are still at a pioneer level where we have to get better acquainted with the specific writings for many archaic words and formulations.

\section{Going Further On}

Going beyond the demotic writing for ritual texts with its many "unetymological", or better "phonological" spellings, even a further step is possible, namely to apply the Greek alphabet to such a ritual text. After all, many scholars, especially those coming from classical studies, think that the Greek alphabet is quite superior to earlier writing systems, not least in its capability to render phonetically accurate and unambiguously the sound of speech (e.g., Havelock 1982; Havelock 1986; Powell 1991). The logic followed so far would indicate that using the Greek alphabet is a logical next step to use on Egyptian ritual texts since its use would be even clearer and 
simpler for guarding the pronunciation of the spells than what could be expressed in demotic writing.

As a matter of fact, there actually are a few compositions which turn this approach into a real practice. However, we have of necessity to add one element to the Greek alphabet to make it viable as a usable medium of rendering Egyptian language. There are some sounds not existing in Greek but important as phonemes in Egyptian. These have to be indicated in any text which seriously intends to notate Egyptian languages in a way enabling easy and correct pronunciation. Thus, the Greek letters are supplemented by a group of signs taken over from one-consonantal signs of the demotic script for the sounds in question. Especially in the earliest texts making use of such signs, you can still feel the groping for the best solution in this domain, with several possible variants of which only one is finally generalized in what becomes the normal Coptic writing system. These early and still experimental texts are nowadays known as "Old-Coptic". However, I should stress that most of them are not directly relevant for my topic because as for the content, they do not reproduce age-old rituals but contemporary texts in a language closely mirroring contemporary speech.

There is only one substantial text which really contributes to the question of traditional ritual texts, even if it poses enormous problems. That the text preserved in papyrus British Museum 10808. By now, there have been some articles and two monographs devoted to it, but we are far from having reached even a basic consensus as to what that papyrus actually is about. ${ }^{32}$ Most often, it has been understood as a sequence of three spells against fever-demons. I personally disagree profoundly and would like to interpret the text as a ritual for gaining favour and affection. Such a divergence of opinion clearly illustrates that the papyrus is far from easily understandable on a semantic level, even if the column is preserved fairly completely and thus neither the legibility of the signs nor lacunae are a major source of problems.

Perhaps I should say more specifically that what has caused such serious problems is actually one column of the text which contains exclusively incantation formulae to be recited. There are some remnants of a second column, and while they are too damaged to yield much connected

${ }^{32}$ Principle studies are Crum (1941); Volten (1953); Osing (1976) with critical reviews by Vergote (1977) and Shisha-Halevy (1980); Sederholm (2006) with critical reviews by Depuydt (2008) and Quack (2009c). 
sense, they are in themselves quite clear and understandable, and this is due to one basic trait: They are written in demotic Egyptian script and employ contemporary language. This fact can by now be augmented by further evidence. There is a still unpublished fragment in the papyrus collection of the EES at Oxford (105/124) which represents almost certainly the upper half of the second column, quite well preserved. In it, the title, the application and the manual instructions are written out in demotic, only the actual incantation makes use of Greek letters, in this case without any obvious background in Egyptian language. This gives us one important key for the overall interpretation. The scribe and user of the papyrus himself was capable of writing and reading demotic but did not deem it the best option for writing down the spells. In this case we can be absolutely sure that he did not intend to convey an additional layer of meaning because a text written almost exclusively in Greek letters and demotic one-consonantal-signs could not possibly function as a commentary in the way alleged for the demotic ritual texts.

Sederholm proposed in his recent edition that the text was alphabetic, but not vocalic and would not have been understandable for another scribe (Sederholm 2006: XIV). I tend to seriously disagree. The very aim of this text was to render as accurately as possible the real contemporary pronunciation of the spell in order to assure the most correct recitation. The use of vowels, in cases where the sense is well enough understood to make a check possible, seems correct and consistent, thus we can suppose that the document was actually intended to convey the sound of the recitation as closely as it was possible with the writing tools available. The break with traditional Egyptian writing traditions this entailed, however, clearly produces a shift in priority. While the phonetic realisation becomes even easier than with any sort of Egyptian writing, the semantic side of the text looses seriously. We can still suppose that an Egyptian ritual specialist would have fewer difficulties than a modern scholar, being more at home with such texts than we can ever hope for. But still the fact that the text is so difficult for us to decode is some indicator towards the problems it would present even to an ancient Egyptian.

In this case, the difficulties are serious even though the use of additional signs derived from demotic one-consonantal signs meant that all existing sounds of the Egyptian language could be appropriately represented. We can imagine how much more difficult things become once we use only the existing Greek letters without additional indication of sounds unknown to Greek. This, however, is what would happen in magical manuscripts of the third to fifth century BCE from Egypt. They are basically 
written in Greek, especially for the manual indications to be performed. The recitations, however, could include sections noted in Greek writing but not simply being Greek. Rather, there was an admixture of Egyptian or Semitic parts. Obviously, semantically decoding these incantations is highly difficult, and modern scholars are far from understanding all of it, even the proposed etymologies for certain sound-sequences (assembled in Brashear 1995) are often controversial and rarely really convincing.

Regardless of the cleverness of modern scholars in decoding them, however, what matters at least equally is how ancient practitioners and listeners reacted to them. We can suppose that quite soon after the forging of the incantations they had no longer any clear idea of what was semantically meant. We can even bolster this claim by recurrence to a well-known ancient discursive passage in Greek. It is found in a treatise where the ritual technique of theurgy is defended, which claims to be based on methods used by Egyptian priests for achieving direct contact with the deity. One point raised by critics was the sequences of "barbaric" words without any discernible clear meaning. The author of the treatise defends their use (Jamblichus, De mysteriis VII 4 f.). As principal argument he adduces that those sound-sequences are dear to the gods regardless of if they are understood by men (des Places 1966: 191-195). They are simply the first ones used in contact with the deity, and their immutability was a virtue in itself. This probably tells us quite a bit about contemporary reactions in the third and fourth century $\mathrm{CE}$, and it is the logical conclusion of the developments in the writing of Egyptian ritual manuscripts I have presented here..$^{33}$

\section{References}

Banaschak, S. \& Th. Grothoff 2000. Osiris-der grüne Totengott, Göttinger Miszellen 175: 17-21

Brashear, W. 1995. The Greek Magical Papyri: An Introduction and Survey; Annotated Bibliography (1928-1994). In W. Haase (ed.), Aufstieg und Niedergang der römischen Welt, Teil II: Principat, Band 18/5, pp. 3380-3684. Berlin/New York: de Gruyter.

Crum, W. 1941. An Egyptian Text in Greek Characters. Journal of Egyptian Archaeology 28: 20-31.

Depuydt, L. 2008. Review of Sederholm 2006. Lingua Aegyptia 16: 349-354.

${ }^{33}$ For the connection of Jamblichus' statement with Egyptian realities, see already Quack (2004: 442). 
Goyon, J.C. 1999. Le papyrus d'Imouthès fils de Psintaês au Metropolitan Museum of Art de New-York (Papyrus MMA 35.9.21). New York: The Metropolitan Museum of Art.

Grenfell, B.A. S. Hunt \& E.J. Goodspeed 1907. The Tebtunis Papyri, Part II. London: Henry Frowde.

Griffith, F.Ll. \& H. Thompson 1904-1909. The Demotic Magical Papyrus of London and Leiden. London: H. Grevel \& Co.

Havelock, E.A. 1982. The Literate Revolution in Greece and its Cultural Consequences. Princeton: Princeton University Press.

1986. The Muse learns to write. Reflections on Orality and Literacy from Antiquity to Present. New Haven/London: Yale University Press.

2002. Die Hymnensammlung des P. Wien D6951. In K. Ryholt (ed.), Acts of the Seventh International Conference of Demotic Studies Copenhagen, 23-27 August 1999, CNI Publications 27, pp. 219-228. Copenhagen: Museum Tusculanum.

Hoffmann, F. in press. Der demotische Papyrus Wien D 6951. In J.F. Quack (ed.), Ägyptische Rituale der griechisch-römischen Zeit. Tübingen: Mohr Siebeck.

Hoffmann, F. \& J.F. Quack 2007. Anthologie der demotischen Literatur. Berlin: Lit-Verlag.

Jasnow, R. \& K.-Th. Zauzich 2005. The Ancient Egyptian Book of Thot. A Demotic discourse on Knowledge and Pendant to the Classical Hermetica. Wiesbaden: Harrassowitz.

Leitz, Chr. et alii 2002. Lexikon der ägyptischen Götter und Götterbezeichnungen, Band II: $o-b$. Orientalia Lovaniensia Analecta 11. Leuven, Paris, Dudley MA: Peeters.

Lippert, S.L. \& M. Schentuleit 2010. Stoetis in geheimer Mission. Der Brief pBerlin P 8092. In H. Knuf, Chr. Leitz, D. von Recklinghausen (eds.), Honi soit qui mal y pense. Studien zum pharaonischen, griechisch-römischen und spätantiken Ägypten zu Ehren von HeinzJosef Thissen, OLA 194, pp. 357-381, pl. 72-74. Leuven, Paris, Walpole, MA: Petters.

Osing, J. 1976. Der spätägyptische Papyrus BM 10808, Ägyptologische Abhandlungen 33. Wiesbaden: Harrassowitz.

1998. The Carlsberg Papyri 2. Hieratische Papyri aus Tebtunis I, CNI Publications 17. Copenhagen: Museum Tusculanum.

des Places, E. 1966. Jamblique, Les mystères d'Égypte. Paris: Les Belles Lettres; ${ }^{4} 2003$.

Powell, B. 1991. Homer and the Origin of the Greek Alphabet. Cambridge, New York: Cambridge University Press.

Pries, A. 2011. Die Stundenwachen-Riten im Osiriskult. Eine Studie zur Tradition und späten Rezeption von Ritualen im Alten Ägypten, Studien zur spätägyptischen Religion 2. Wiesbaden: Harrassowitz.

Quack, J.F. 1991. Über die mit ' $n h$ gebildeten Eigennamen und die Vokalisation einiger Verbalformen. Göttinger Miszellen 123: 91-100.

1999a. Weitere Korrekturvorschläge, vorwiegend zu demotischen literarischen Texten. Enchoria 25: 39-47.

1999b. Review of W. Westendorf, Handbuch der altägyptischen Medizin. Orientalistische Literaturzeitung 96: 455-462.

- 2001. Ein Standardhymnus zum Sistrumspiel auf einem demotischen Ostrakon (Ostrakon Corteggiani D 1). Enchoria 27: 101-119, pl. 4.

- 2004. Griechische und andere Dämonen in den demotischen magischen Texten. In Th. Schneider (ed.), Das Ägyptische und die Sprachen Vorderasiens, Nordafrikas und der Ägäis. Akten des Basler Kolloquiums zum ägyptisch-nichtsemitischen Sprachkontakt Basel 9.-11. Juli 2003, Alter Orient und Altes Testament 310, pp. 427-507. Münster: UgaritVerlag.

— 2005. Ämtererblichkeit und Abstammungsvorschriften bei Priestern nach dem Buch vom Tempel. In M. Fitzenreiter (ed.), Genealogie-Realität und Fiktion von Identität, IBAES V, pp. 97-102. London: Golden House Publications.

- 2006. Die Rolle der Hieroglyphenschrift in der Theorie vom griechischen Vokalalphabet. In W. Ernst, F. Kittler (ed.), Die Geburt des Vokalalphabets aus dem Geist der Poesie. Schrift, Zahl und Ton im Medienverbund, pp. 75-98. München: Wilhelm Fink. 
2007a. Die Initiation zum Schreiberberuf im Alten Ägypten. Studien zur Altägyptischen Kultur 36: 249-295.

2007b. Ein ägyptischer Dialog über die Schreibkunst und das arkane Wissen. Archiv für Religionsgeschichte 9: 259-294.

2008. Demotische magische und divinatorische Texte. In B. Janowski, G. Wilhelm (ed.), Texte aus der Umwelt des Alten Testaments, Neue Folge Band 4. Omina, Orakel, Rituale und Beschwörungen, pp. 331-385. Gütersloh: Gütersloher Verlagshaus.

- 2009a. Difficult Hieroglyphs and unreadable Demotic? How the Ancient Egyptians dealt with the Complexity of their Script. In A. de Voogt \& I. Finkel (eds.), The Idea of Writing. Play and Complexity, pp. 235-251. Leiden: Brill.

2009b. Egyptian Writing for non-Egyptian Languages and vice-versa-a short overview. In A. de Voogt \& I. Finkel (eds.), The Idea of Writing. Play and Complexity, pp. 317-325. Leiden: Brill,.

2009c. Review of Sederholm 2006. Orientalistische Literaturzeitung 104: 27-33.

- 2009d. Review of D. Kurth, Einführung ins Ptolemäische, Teil 1. Die Welt des Orients 39: 140-149.

_ in press a. Eine Götterinvokation mit Fürbitte für Pharao und den Apisstier (Ostrakon Hor 18). In J.F. Quack (ed.), Ägyptische Rituale der griechisch-römischen Zeit. Tübingen: Mohr Siebeck.

in press b. Bemerkungen zur Struktur der demotischen Schrift und zur Umschrift des Demotischen. In M. Depauw (ed.), Acts Demotistentagung Leuven 2008.

Ryholt, K. 1999. The Story of Petese, Son of Petetum and Seventy Other Good and Bad Stories, CNI Publications 23. Copenhagen: Museum Tusculanum.

Sederholm, V.H. 2006. Papyrus British Museum 10808 and its Cultural and Religious Setting. Probleme der Ägyptologie 24. Leiden: Brill.

Shisha-Halevy, A. 1980. Review of Osing 1976. Journal of Egyptian Archaeology 66: 181-186. Smith, M. 1977. A New Version of a Well-Known Egyptian Hymn. Enchoria 7: 115-149, pl. 18.

1979. The Demotic Mortuary Papyrus Louvre E. 3452. Dissertation University of Chicago.

1987. Catalogue of Demotic Papyri in the British Museum III. The Mortuary Texts of Papyrus BM 10507. London: British Museum.

1999. O. Hess $=$ O. Naville $=\mathrm{OBM}_{50601}$ An Elusive Text Relocated. In E. Teeters \& J.A. Larson (eds.), Gold of Praise, Studies on Ancient Egypt in Honor of Edward F. Wente, Studies in Ancient Oriental Civilisations 58, pp. 397-404. Chicago: University of Chicago Press.

- 2005. Papyrus Harkness (MMA 31.9.7). Oxford: Griffith Institute.

- 2009a. Traversing Eternity. Texts for the Afterlife from Ptolemaic and Roman Egypt, p. 392. Oxford: Oxford University Press.

200gb. New Extracts from the Book of the Dead in Demotic. In D. Devauchelle \&

G. Widmer (eds.), Actes du LX congrès international des études démotiques Paris, 37 août3 septembre 2005, Bibliothèque d'Études 147, pp. 347-359. Cairo.

2010. A Divine Decree for the Deceased (O. Strasbourg D. $132+133+134)$. In H. Knuf \& Chr. Leitz, D. von Recklinghausen (eds.), Honi soit qui mal y pense. Studien zum pharaonischen, griechisch-römischen und spätantiken Ägypten zu Ehren von Heinz-Josef Thissen, OLA 194, 439-4454, pl. 81-83. Leuven, Paris, Walpole, MA: Petters,

in press. Bodl. MS. Egypt. a. $3(\mathrm{P})$ and the Interface Between Temple Cult and Cult of the Dead. In J.F. Quack (ed.), Ägyptische Rituale der griechisch-römischen Zeit.

Stadler, M. 2005. Das Ritual, den Tempel des Sobek, des Herrn von Pai, zu betreten: ein Ritualtext aus dem römischen Fayum. In H. Roeder \& B. Dücker (eds.), Text und Ritual. Kulturwissenschaftliche Essays und Anahysen von Sesostris bis Dada, pp. 149-163. Heidelberg: Synchron.

2006. Isis würfelt nicht. Studi di Egittologia e di papirologia 2: 187-203. 
2007. Zwischen Philologie und Archäologie: Das tägliche Ritual des Tempels in Soknopaiou Nesos. In M. Capasso (ed.), New Archaeological and Papyrological Researches on the Fayyum. Proceedings of the International Meeting of Egyptology and Papyrology Lecce, June 8th-10th 2005, Papyrologica Lupiensia 14, pp. 283-302. Lecce: Congedo.

Vergote, J. 1977. Review of Osing 1976. Bibliotheca Orientalis 34: 135-139.

Vleeming, S. 1990. Translitterating Old Egyptian in Demotic. Göttinger Miszellen 117/118: 219-223.

- 2004. A Hieroglyphic-Demotic Stela from Akhmim. In F. Hoffmann \& H.J. Thissen (eds.), Res severa verum gaudium. Festschrift für Karl-Theodor Zauzich zum 65. Geburtstag am 8. Juni 2004, Studia Demotica 6, pp. 623-637. Leuven, Paris, Dudley MA: Peeters.

Volten, A. 1953. An Egyptian Text in Greek Characters. In Studia Orientalia Ioanni Pedersen sepuagenario a.d. VII Id. Nov, anno MCMLIII a colleges discipulis amicis dedicata, pp. 364-376. Kopenhagen: Munksgaard.

Widmer, G. 1998. Un papyrus démotique religieux du Fayoum. P. Berlin 6750. Bulletin de la Société d'Égyptologie de Genève 22: 83-91.

2004. Une invocation à la déesse (tablette démotique Louvre E 10382). In F. Hoffmann \& H.J. Thissen (eds.), Res severa verum gaudium. Festschrift für Karl-Theodor Zauzich zum 65. Geburtstag am 8. Juni 2004, Studia Demotica 6, pp. 651-686, pl. 51. Leuven, Paris, Dudley MA: Peeters.

- 2005. On Egyptian Religion at Sokonopaiou Nesos in the Roman Period (P. Berlin 6750). In S. Lippert \& M. Schentuleit (eds.), Tebtynis und Soknopaiou Nesos. Leben im römerzeitlichen Fajum, pp. 171-184. Wiesbaden: Harrassowitz.

2007. Sobek who arises in the primeavel Ocean (PBM EA $7663_{3} 8$ and PStrasbourg dem. 31). In M. Capasso \& P. Davoli (eds.), New Archaeological and Papyrological Reearches on the Fayyum. Proceedings of the International Meeting of Egyptology and Papyrology Lecce, June 8th-1oth 2005, Papyrologica Lupiensia 14, pp. 345-354. Lecce: Congedo.

Zauzich, K.-Th. 1998. Ein vieldiskutiertes Wort im Titel des Hieros Polos der Königin Kleopatra III. In W. Clarysse, A. Schoors \& H. Willems (eds.), Egyptian Religion, The Last Thousand Years. Studies Dedicated to the Memory of Jan Quaegebeur, Orientalia Lovaniensia Analecta 84, pp. 747-750. Leuven: Peeters. 